\title{
The Determinants of the Quality of Financial Information Disclosed by French Listed Companies
}

\author{
Jouini Fathi \\ Faculty of economic and management of Sousse, Tunisia \\ fathijouini@fdseps.rnu.tn
}

\section{Doi:10.5901/mjss.2013.v4n2p319}

\begin{abstract}
This study examines the relationship between the quality of financial information disclosed and governance mechanisms on certain features of the board, ownership structure and control system for French companies listed on the SBF 250 for a period of five years from 2004 to 2008. The quality of financial information is approximated by the discretionary accruals and with a disclosure index with 78 items. The result shows a positive effect of certain variables such as the size of the board of directors, the members' attendance at Board meetings and the presence of the Big 4 and the presence of a dual listing.
\end{abstract}

Keywords:disclosure, corporate governance, accruals, characteristics of the board

\section{Introduction}

The beginning of the first decade of the 21st century was marked by several scandals, fraud and manipulating all kinds of information. Scandals are established in the presence of misdeeds committed by director belonging to the large companies and normally supposed to be trustworthy person. These executives cannot effectively use or divert funds and overestimate the value of assets with the cooperation of officials in other companies or subsidiaries.

These poor practices are considered an evidence of the failure of current models of corporate governance, and the presence of risk of disclosure lack. These scandals renewed debates about the relative merits of the accounting principles adopted in the United States and led to the introduction of new laws.

A company must provide to its shareholders, regulators and markets through the annual reports financial information with higher quality. It is a necessary factor for good governance. Thus, the disclosure is closely linked to the practice of good corporate governance. Improving corporate governance is considered among the themes that have attracted the attention of researchers in finance and since the scandals that took place in the early 2000s (Gaint et al, 2009).

The traditional literature on corporate governance has proposed a solution to the problems of control by implementing of incentive contracts. These were supposed to solve the problems concerning the cost of access to perfect information and the incapacity of shareholders to deal correctly information. Incentive mechanisms seek to achieve a concordance between the interests of the manager and shareholders. Since the 1990s the solution to the problem of information asymmetry appears to be supported by the disclosure of financial information (Gainet et al., 2009). Voluntary or mandatory disclosure would have the merit to reduce information asymmetries and enable effective monitoring of management, and thereby establish good governance. Managers tend to provide voluntary disclosures to make investors aware of their ability to manage and avoid mispricing of their actions and performance. They are likely to provide voluntary disclosures and forecasts to show to investors that they are interested in the evolution of the economic environment in which the company operates and they are able to respond quickly to changes (Gaint et al., 2009). This is a positive signal to investors about the abilities of managers, and has a positive effect on stock returns and on the market value of the firm (La Porta, Lopez de Silanes, Shleifer, and Vishny, 2000). Information disclosed should have certain quality. It must be reliable and relevant to help users and stakeholders in the decision making. For this reason, it is necessary to detect the determinants of the quality of information disclosed. The theoretical arguments that justified the selection of the determinants of financial disclosure are the presence of agency costs, properties cost, political cost, litigation cost and signal theory (Healy and paleplu, 2001; Watson, Shrives and Marston, 2002). 
It is generally accepted that certain characteristics of the company have an impact on the level and the quality of financial information disclosed. However, what firm-specific characteristic is supposed to influence the level and the quality of financial information disclosed?

Several variables concerning profitability and market structure can explain the firm behavior to disclose voluntarily financial information such as firm size, leverage, profitability, size of audit firm, and the status of listing (Barako et al. 2006; Chavent et al, 2006; Ho and Taylor, 2007 Cheung, 2010).

The second category of factors that affect the quality of financial disclosure incorporates the features of corporate governance (Bushman, Piotroski and Smith, 2004). This study seeks to provide possible determinants of the extent of corporate disclosure for French listed companies. These determinants precisely concern corporate governance variables. To assess the quality of financial information disclosed, various measurement methods were used. For this study, the first measure is the abnormal accruals estimated by the model of Shahrur and Raman (2008). According to Francis et al, (2005), a high level of abnormal accruals implies low quality of accounting income and increases the level of risk among investors. The second measure used is the construction of an unweighted disclosure index composed by 78 items.

The rest of this study will be presented as follows: the second section examines the presentation of literature on the disclosure quality determinants, section three presents the model and the sample, the fourth section discusses the interpretation and analysis of results. At last, fifth section provides the conclusion of study.

\section{Literature review}

Among determinants of the level and the quality of financial information disclosed there are firm-specific factors and factors related to mechanism governance.

The variables explanatory disclosure quality about firm characteristics can be grouped into three groups. The variables related to the structure, performance and market (Lang and Lundholm, 1993; Leventis and Weetman, 2004). The variables considered in our study are leverage, profitability, listing status and industry. The literature has also shown that the quality of financial information disclosed is affected by the mechanisms of corporate governance on the characteristics of the board, on the ownership structure and on effective control. Corporate governance factors may encourage firm to disclosure more financial information. The effectiveness of these mechanisms is reflected by good corporate governance system.

\subsection{The characteristics of the firm}

\subsubsection{Leverage}

According to the agency theory (Jensen and Meckling, 1976), a company with a higher debt ratio has an incentive to disclose more information. Creditors can protect themselves by restrictive covenants in debt. Managers have incentives to increase disclosure to reduce agency costs. Disclosure of financial information reduces agency costs and facilitates to creditors the risk assessment of the company (Botosan and Plumlee, 2002). Creditors likely ask more information to ensure their funds. From these explanations, we anticipate that the relationship between the quality of disclosure of financial information and leverage is positive.

\subsubsection{The profitability}

The signaling theory suggests that if a company is profitable, it could disclose more information to indicate the credibility of its reported earnings, to increase its reputation and to avoid undervaluation of its equity (Inchausti 1997).The profitability of the company shows information that may be interest to users of financial information. (Wallace, Naser, and Mora, 1994). It is generally argued that the manager of the most profitable companies disclose more financial information to signaling and adverse selection incentives (Verrecchia, 1983, Lang and Lundholm, 1993). Firms tend to communicate more frequently information when the result is positive (Akhtaruddin , 2005).Managers have incentives to disclose information in order to reduce of legal liability (Lang and Lundholm, 1993; Ho and Taylor, 2007). These arguments lead us to predict a positive relationship between profitability and financial disclosure. 


\subsubsection{The industry}

Membership in a particular industry can be considered as an explanatory factor for the disclosure of financial information. (Leventis and Weetman, 2004). For example, manufacturing firms have characteristics that relate to competition, product differentiation, growth, demand volatility, and risks. These companies may have a framework for the disclosure policy differentiated (Dye and Sridhar, 1995). We expect the existence of a relationship between financial disclosure and industry

\subsubsection{The listing status}

Listing status is a factor explaining the variability of financial disclosure. Companies may have three status, unlisted, listed only on the local market or at a single exchange stock market or quoted on several stock market (multiple listing). Fama and Jensen (1983) argue that an IPO is an incentive to reduce conflicts between the contracting parties. Firms with different status listing levels may disclose information voluntarily because they have different objectives regarding the development and growth of capital. Companies with multiple listing are looking to expand their activities abroad (Cooke, 1991). Multiple listing allows the company to provide an advertisement by the attraction of the press and to satisfy information requirements by local users. It also allows access to a financial market more liquid and less segmented than its local market. When company is listed on the international market, there are obligations to disclosure additional information than national requirements. This leads us to assume that quality of information disclosed increases when the company has a multiple listing.

\subsection{Board of Directors's Characteristics}

According to the agency theory the characteristics of the board can affect the quality and the level of financial information disclosed by company. Several theoretical and empirical studies examined this issue such as the studies of Jensen (1983); Healy and Palepu (2001); Ho and Wong (2001), Bujaki and McConomy (2002), Clarkson et al, (2003), Barako et al. (2006) and Cheung (2010).

These features concern:

- The size of the Board;

- The presence of independent directors;

- Dual functions of Chief Executive Officer and Chairman of the Board;

- The attendance of Board members at meetings.

\subsubsection{The size of the board}

The size of the board is a decreasing function of the effectiveness of control. When adding a new member to the board of directors enhances the board's oversight capacity. However, this is offset by implication the marginal cost of an additional member in terms of taking control and information disclosure (Jensen, 1993). In this case, the marginal cost increases when we add members to the board, by cons, the control and its effectiveness decreases. According to Jensen (1993), the boards consist of more than seven or eight directors are more easily controllable by the manager. Campos et al, (2002) noted that the size of the board should not be too large or too small and suggested an optimum number is between 5 to 9 members. Large boards may contain mechanisms for entrenchment (Yermack, 1996; Godard, 2001). Indeed, a large board has a negative impact on its performance. A large board increases problems of communication and coordination and also reduces the ability of directors to oversee management. It causes an increase in manipulation of earnings by manager and production information with poor quality. Through these points of view, we expect that there is a relationship between the size of the board and the quality of the information disclosed.

\subsubsection{The proportion of independent directors}

Independent directors can be officers of others companies or representatives of financial institutions. Based on their experience, independent directors can contest decisions made by managers and therefore exercise more effective control. The independent directors act as a reliable mechanism to reduce agency conflicts between managers and 
shareholders (Fama and Jensen, 1983). They provide the necessary checks to improve the effectiveness of the Board (Franks et al, 2001). These directors assemble the conditions of objectivity and independence. By providing efficient control, independent directors seek to improve their reputation in the labor market (Fama, 1980). The relationship between the proportion of independent directors on the board and financial disclosure quality within the company was provided by Haniffa and Cooke (2002), Chen and Jaggi (2000), Arcay and Vazquez (2005). They found a positive effect of the existence of independent directors on the disclosure of financial information. Based on these explanations, our hypothesis is as follow: The proportion of independent directors affects positively the quality of financial information disclosed.

\subsubsection{Separation of function of Chief Executive Officers and Chairman of the Board}

According to the agency theory, the combined functions can significantly alter the most important function of the Board that is the control, discipline and compensate executives. It also allows to the manager to adopt opportunistic behavior, because of its domination of the board. Manager can easily impose investments that he proposes even if these investments do not create value for shareholders. According to agency theory the separation of management and control decisions reduces agency costs and increase firm performance. A person who combines both functions would tend to withhold unfavorable information outside. All negative consequences of duality could be eliminated by market discipline (Fama and Jensen, 1983).

Separation of function is not always adopted by companies. There is many companies are well managed with combined functions. In the presence of combination of functions, it will be easier for the CEO to achieve the objectives of the company because there will be less interference and therefore contributes to enhancing business leadership and guidance (Dahya, Lonie, and Power, 1996). Their arguments are based on the theory of stewardship, which implies that managers act in the best interests of the company and shareholders, and as such, the duality can improve the effectiveness of the board (Hanifa and Cook, 2002). Empirical studies dealing with the combination of functions gave mixed results. Among the studies that are for the separation of functions, among them there are Ho and Wong, (2001), Gul and Leung, (2004).

Through these arguments we can formulate our hypothesis as follows: the relationship between separation of function (CEO and Chairman) and the quality of financial information is positive

\subsubsection{The frequency of meetings and the attendance of members of the Board of Directors meetings}

Meeting frequency can be considered as a measure of the activity of the Board of Directors (Xie et al, 2003). When the number of meetings increases, the operating performance of the company is improved (Vafeas, 1999). This suggests that the frequency of meetings is an important aspect in the effectiveness of the Board. The board that meets more frequently, should be able to devote more time to issues such as performance management and hence to the quality of the information. To control the production of information at board meetings and participate in decision making, the attendance of members at meetings can be considered as a determinant of the quality of the work of the board (Ben Ayed-Koubaa, 2010). Thus, this discussion suggests the following hypothesis: attendance at meetings by the board affects positively the quality of financial information disclosed

\subsection{Audit quality}

Among mechanisms of control adopted by firm to inspect financial information quality there are the external auditor and the audit committee.

\subsubsection{The external auditor}

Audit function has a key role in the control of the management of companies where the owners do not provide stewardship. An external audit can significantly influence the amount of information disclosed. This relationship is consistent with agency theory; an audit firm with large size has a strong incentive to maintain their independence and to impose more stringent disclosure standards because they have more to lose from damage to their reputation. The large audit firms invest more to maintain their reputation as providers of effective control that small audit firms (DeAngelo, 1981). The independence enjoyed by a large company audit allows them to influence corporate financial information 
disclosed, to satisfy the needs of external users for reports, since their values as auditors depend on the nature of user perception of financial information (DeAngelo, 1981).

Signal theory suggests that the choice of an external auditor can serve as a signal of the value of the company. In general, entrepreneurs are likely to choose a large audit firm size (eg, Big 4) because it is a signal to investors. The choice of audit firm has been found to be a signal of firm value. The presence of Big4 is considered as a signal quality of the disclosure of the company and the integrity of financial information (Datar, Feltham and Hughes, 1991). The agency theory suggests that external audit have a role in mitigating the conflict between management and shareholders (Xiao et al, 2004, Jensen and Meckling 1976). This suggests that firms with higher agency costs will be more inclined to obtain higher quality audits by contacting large audit firms. Studies of Xiao Yang and Chow (2004), Leung et al, (2005) and Wang et al, (2008) found a relationship between the size of audit firm and the disclosure quality of financial information by companies. Through these arguments, we expect a positive relationship between the quality of financial disclosed and the presence of a Big 4 .

\subsubsection{The presence of audit committee}

The Board of Directors may delegate certain functions to specialized committees such as the audit committee. The function of an audit committee, ensure the quality of financial accounting and control system. The agency theory suggests for the establishment of audit committees to reduce agency costs. The presence of an audit committee is associated with reliable financial information. It reduces the impact of errors and irregularities (McMullen, 1996). The Board of directors delegates responsibility to the audit committee to enhance the relevance and reliability of financial information disclosed. Thus, audit committees can be considered as a monitoring mechanism that improves the quality of information flow between shareholders and managers, especially in the financial information environment, where the level of information detained by users is heterogeneous. From these explanations, we expect a positive relationship between the presence of an audit committee and the quality of information disclosed

\subsection{The ownership structure}

Among aspects of ownership structures there are concentration of ownership and institutional ownership

\subsubsection{The percentage held by major shareholders}

The agency theory suggests that in a modern society, due to the separation of ownership and control, there is a possibility of agency conflicts (Jensen and Meckling, 1976). This conflict may be more important when shares are widely distributed than when they are held by one person (Fama and Jensen, 1983). Managers can therefore voluntarily disclose information as a means to reduce agency conflicts with the shareholders. The concentration of capital can be considered as an assurance of effectiveness monitoring the labor of managers by shareholders (Denis et al., 1997). Major shareholders have the possibility to monitor easily managers in order to protect their investment, as opposed to minority shareholders who have limited financial resources. When capital is concentrated, major shareholders may pose a threat of expropriation for minority and they are therefore predisposed to disclosure financial information. Indeed, a good disclosure can protect minority shareholders. The major shareholders have a strong interest in the performance of the firm and therefore increase the capacity of voluntary disclosure. As Barako et al (2006) Li et Qi (2008), we predict that there is a relationship between the concentration of capital and the quality and level of disclosure.

\subsubsection{The percentage of shares held by institutional shareholders}

Institutional investors collect large amounts from the public and invest in the capital of large corporations. Vast importance is given to these investors. They are more severe in terms of regular financial information and published in a timely manner (Healy et al, 1999). Their property in the capital of a company can reduce agency costs. Where such participation is important, institutional investors may force managers to improve the quality of published information. The presence of institutional investors can be seen as a governance mechanism. Indeed, because of the large amounts invested in the company, institutional investors have the motivation to intervene very active in the management of the firm and may also have the motivation to monitor managers (Jensen, 1993). In this context, we can predict that the presence of institutional investors has a positive effect on the quality and level of disclosure; 


\section{The presentation of data and variables}

\subsection{The presentation of data}

In order to test the relationship between the mechanisms of governance and the quality of information, we have selected a sample of French listed companies in the SBF 250 index. The study period is from 2004 until 2008. To ensure consistency of the sample, financial institutions (banks and insurance companies) were excluded because they are subject to specific regulations concerning publication. We eliminated firms with missing data (financial and governance data). In the end, the sample is composed by 101 companies. For accounting and financial data we have obtained from the Worldscope database. The data concerning the mechanisms of governance collected manually from annual reports.

Table 1. Methodology of sample selection

\begin{tabular}{|l|c|}
\hline & Number of firms \\
\hline Companies listed on the SBF 250 & 250 \\
\hline Financial institutions (banks and insurance) & 46 \\
\hline Missing reports for the entire period & 35 \\
\hline Unlisted companies across the period & 14 \\
\hline Missing data & 55 \\
\hline Sample & 101 \\
\hline
\end{tabular}

Companies components our samples are divided into three sectors. The table below shows the number of firms by sector:

Table2. The distribution of firms by industy

\begin{tabular}{|l|c|c|}
\hline Industry & Number of companies & pourcentage \\
\hline Manufactoring & 55 & $54.46 \%$ \\
\hline Services & 23 & $22.77 \%$ \\
\hline Communication & 23 & $22.77 \%$ \\
\hline
\end{tabular}

\subsection{Presentation of variables}

\subsubsection{Quality of Financial Information}

The dependent variable in this empirical study is the quality of financial information disclosed. This variable has approximated by the disclosure index and the discretionary accruals:

For the construction of the disclosure index unweighted, we consulted the following documents:

- Previous empirical studies that aims to identify best practices of disclosure of financial information whose main support is the annual report (Haniffa et Cook, 2002; Collet and Hrasky, 2005; Hassan et al, 2006; Bangh and Plenborg, 2008).

- Some annual reports of listed companies;

- French financial market authority recommendations on financial information disclosed of listed companies.

The items selected should have certain characteristics in order to eliminate those that may skew the understanding of extent disclosure practices of companies. In fact, the items must generally be disclosed by all firms. It should not be very specific for one activity. The information published in our index should have importance of the perspective of any user. Our disclosure index include voluntarily and mandatory information. This choice helps to increase the number of items inserted. Our aim is to construct an index that measures the level and quality of disclosure. At the international level, there are studies that used only the mandatory information; there are also those who have opted for information 
disclosed only on a voluntary basis. The score may be an indicator of quality. The items selected must complete the main characteristics of financial information disclosed: relevance, reliability, understandability.

Taking into account its criteria we grouped the items into six categories to reach 78 items:

Table3.: Distribution of items by category of information

\begin{tabular}{|l|c|}
\hline Category of items & number of items \\
\hline A-General Information and Strategic & 13 \\
\hline B-Information on the financial statements & 12 \\
\hline C-The Social and environmental data & 6 \\
\hline D-The Corporate Governance & 18 \\
\hline E-Market and financial information & 18 \\
\hline F- Forecast information & 4 \\
\hline G- Other information & 7 \\
\hline TOTAL & 78 \\
\hline
\end{tabular}

The extent of disclosure index is calculated as follows:

$$
U I_{a}=\frac{1}{m} \sum_{i=1}^{n} d_{i}
$$

UI: unweighted index

D: items of information disclosed by the company

$\mathrm{m}$ : is the maximum number of items that the Company may disclose

The discretionary accruals.

The second measure of financial information quality is the discretionary accruals. For Francis et al, (2005) discretionary accruals is considered as an indicator of the quality of financial information disclosed. For this study the discretionary accruals estimated by the model of Shahrur and Raman (2008). This is the model of Kothari et al, (2005) extended by book-to-market

For this model the total accruals are calculated as follows:

$$
\frac{\operatorname{TACC}_{i t}}{\operatorname{ASSETS~}_{i t-1}}=\alpha_{1}\left(1 / \operatorname{ASSETS~}_{i t-1}\right)+\alpha_{2} \frac{\Delta \operatorname{SALES}_{i t}}{\operatorname{ASSETS}_{i t-1}}+\alpha_{3} \frac{\operatorname{PPE}_{i t}}{\operatorname{ASSETS}_{i t-1}}+\alpha_{4} \text { ROA }_{i, t}+\text { BM }_{i, t}+v_{i t}
$$

We calculated the total accruals as the difference between net income and operating cash flow.

$$
N A_{i t}=\hat{\alpha}_{1} \frac{1}{\text { Asset }_{i t-1}}+\hat{\alpha}_{2} \frac{\Delta S A L E S_{i t}}{\text { Asset }_{i t-1}}+\hat{\alpha}_{3} \frac{P P E_{i t}}{\text { Asset }_{i t-1}}+\hat{\alpha}_{4} R O A_{i t}+\hat{\alpha}_{5} B M_{i t}
$$

The discretionary accruals (DACC) in year $t$ are calculated as the difference between total accruals and normal accruals (NA) as follows: 


$$
\operatorname{DACC}_{i, t}=\frac{T A_{i, t}}{\operatorname{Asset}_{i, t-1}}-N A_{i, t}
$$

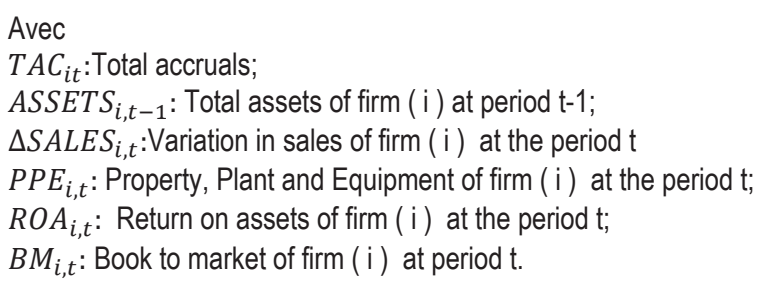

\subsubsection{Explanatory variable}

We try to explain the quality of the financial information based on several variables mentioned throughout the literature. These variables are related to the characteristics of the company, and on the internal mechanism of governance.

We approximated leverage by the ratio (total debt / total assets), among the authors who have used this measure, we can mention Khanna, Palepu and Srinivasan (2004), Leventis and Weetman (2004), Barako et al, (2006), Hassan, Giorgioni and Romilly (2006), Aksu and Kosedag (2006), Zeghal et al, (2006), Lu, Liao and Yang (2007), Agca and Onder (2007), Ho and Taylor (2007) and Jiang et al. (2008).

We approximated Profitability by the market by Tobin's $Q$ as the studies of Khanna, Palepu and Srinivasan (2004) Cheung et al, (2006); Lu, Liao and Yang (2007).

Tobin's $Q=$ (market capitalization + market value of debt) /Replacement cost of assets

We approximated status listing by a binary variable. We give the value 1 if the firm has a dual listing and 0 otherwise. Several researchers used this variable such as Cooke (1989), Wallace et al, (1994), Inchausti (1997), Leventis and Weetman (2004), Prencipe (2004), Arcay and Vazquez (2005), Leung et al. (2005)

We divided sample into three industries (manufacturing, services and communication). On our model, we have three binary variables. Assigned the value 1 if the firm (i) belongs to sector (j), and 0 otherwise. We seek any sector discloses more financial information (Cooke, 1989; Raffournier, 1995; Archambault and Archambault, 2003; Hanifa and Rashid, 2005; Akhtaruddin, 2005; Hassan, Giorgioni and Romilly, 2006 and Jiang et al, 2008).

For the Board of Directors, it is represented by several variables:

The size of the board is approximated by the number of directors on the board, Godard (2001) and Fernández and Arrondo (2005) and Zeghal et al, (2006).

The attendance of members at meetings as measured by percentage of attendance of members at meetings (Vafeas, 1999; Xie et al, 2003 and Ben Ayed-Koubaa, 2010).

The presence of independent directors as measured by the proportion of independent outside directors on the board (Arrondo and Fernández, 2005; Barako et al, 2006 and Zeghal et al, 2006)

The duality function of CEO and chairman is measured by a binary variable that takes the value 1 in the presence of dual function and 0 otherwise. Several previous researches opted for this measure, such as Brickley et al. (1997), Godard and Schatt (2000) Chtourou et al, (2001) and Zeghal et al, (2006).

Audit quality approximated by two variables: The presence of the audit committee measured by a binary variable, assigned 1 when companies have an audit committee and 0 otherwise.

The size of audit firm approximated as follow: Assigned the number 1 if the firm is audited by one auditor belonging to the big 4 and 0 otherwise.

Ownership structure represented by the ownership concentration measured by the percentage owned by the major shareholder, this measure is also used by Godard (2001) and Fernández and Arrondo (2005) and Zeghal et al, (2006). The presence of institutional investors is measured by a binary variable. Assigned the value 1 if institutional investors have more than $5 \%$ of capital and 0 otherwise. 


\section{Analysis and interpretation of results}

At the analysis result we will proceed with the analysis of the variables used in our model by the descriptive analysis, the determination of the bivariate correlation and multivariate between the explanatory variables finally we will make an estimate based on the regression in Panel data.

\subsection{The descriptive analysis}

\subsubsection{The descriptive statistics}

Descriptive statistics of dependent and independent variables are shown in Table 3.

From the descriptive statistics we observe that on average, Tobin's $Q$ is greater than 1 . It demonstrates the presence of important performance related to market for French companies and growth opportunities. $64 \%$ of the sample has a dual structure; attendance at meetings of the board of directors is on average $86 \%$. The board met on average 6 times per year (6.68). On average, boards are large, the average size is 10, it is a value greater than the optimum set by Jensen (1993) that is 9 members. According to this author a board composed of more than seven or eight directors is more easily controllable by the manager. Campos et al (2002) noted that the size of the board should not be too large or too small and suggested an optimum number is between 5 to 9 members. The half of the members of the Board is independent $(43.83 \%)$. Among $69 \%$ of companies have officers whose exercise both the functions of CEO and chairman of the board. And $80 \%$ of companies have an audit committee.

Table 3. Descriptive statistics of variables

\begin{tabular}{|l|r|r|r|r|r|}
\hline Variable & Obs & \multicolumn{1}{|c|}{ Mean } & \multicolumn{1}{c|}{ Std, Dev, } & \multicolumn{1}{c|}{ Min } & \multicolumn{1}{c|}{ Max } \\
\hline DI & 505 & 0,7991594 & 0,0702844 & 0,5896 & 0,9231 \\
\hline DACC & 505 & $-0,0273578$ & 0,1123514 & $-1,658396$ & 0,6701526 \\
\hline LEV & 505 & 0,2438619 & 0,1486237 & 0 & 0,7568396 \\
\hline PRO & 505 & 1,342008 & 1,914398 & 0,2142435 & 36,3984 \\
\hline NB & 505 & 9,962376 & 3,83289 & 3 & 21 \\
\hline IND & 505 & 0,4383567 & 0,1981265 & 0 & 1 \\
\hline DUA & 505 & 0,6891089 & 0,4633173 & 0 & 1 \\
\hline INST & 505 & 0,4772277 & 0,4999764 & 0 & 1 \\
\hline OWN & 505 & 0,3328322 & 0,2108464 & 0,02 & 0,9168 \\
\hline Number of meeting & 505 & 6,685149 & 2,950295 & 2 & 30 \\
\hline MA & 505 & 0,8591924 & 0,0861177 & 0,5 & 1 \\
\hline AC & 505 & 0,7980198 & 0,4018756 & 0 & 1 \\
\hline BIG4 & 505 & 1,281188 & 0,657785 & 0 & 2 \\
\hline MAN & 505 & 0,5247525 & 0,4998821 & 0 & 1 \\
\hline SERV & 505 & 0,2277228 & 0,4197786 & 0 & 1 \\
\hline COM & 505 & 0,2376238 & 0,4260495 & 0 & 1 \\
\hline
\end{tabular}

DI: disclosure Index; DACC: discretionary accruals; Lev : leverage PRO: The Profitability (Qtobin) ; NB: numbers of members in board ; IND independent directors (members extern / total members in board); MA: percentage of attendance of members at meetings ; DUA duality of function for manager; INST The institutional investors ; OWN : the percentage owned by the majority shareholder ; AC: Audit Committee; BIG4 presence of an auditor belonging to BIG4; ML: multiple listing; MAN, SERV and COM designed respectively manufacturing, service and communication industry. 


\subsubsection{The bivariate and multivariate correlation}

The correlation between two variables is detected by the Pearson correlation matrix. The bivariate test shows the presence of a low correlation between explanatory variable. The correlation not exceeds $30 \%$.

To assess multicollinearity, the regression should be performed with each exogenous with other variables and examine the coefficient of determination associated. Indicators of multivariate correlation, we have: Factor variance inflation (VIF) and tolerance.

There is a problem when the coefficient of collinearity (VIF) greater than 4. Some authors use less restrictive thresholds ie 5 or even 10 . The objective of this analysis is to identify the variables that cause the most problems in the regression.

The result of the tests shows absence of multicollinearity between explanatory variables. All VIF values are identified below the treeline fixed by Groebner et al., (2005), that is 5 .

Table4. Pearson correlation matrix

\begin{tabular}{|c|c|c|c|c|c|c|c|c|c|c|c|c|}
\hline & LEV & PRO & NB & IND & DUA & INST & OWN & MA & AC & BIG4 & ML & VIF \\
\hline LEV & 1.00 & & & & & & & & & & & 1.22 \\
\hline PRO & -0.212 & 1.000 & & & & & & & & & & 1.12 \\
\hline NB & 0.122 & -0.193 & 1.000 & & & & & & & & & 1.79 \\
\hline IND & 0.104 & -0.118 & 0.168 & 1.000 & & & & & & & & 1.57 \\
\hline DUA & -0.035 & 0.048 & -0.062 & -0.184 & 1.000 & & & & & & & 1.17 \\
\hline INST & 0.045 & -0.056 & 0.269 & 0.213 & 0.016 & 1.000 & & & & & & 1.20 \\
\hline OWN & -0.088 & 0.014 & -0.214 & -0.299 & 0.059 & -0.115 & 1.000 & & & & & 1.31 \\
\hline MA & 0.086 & -0.017 & 0.045 & 0.159 & -0.13 & 0.176 & 0.002 & 1.000 & & & & 1.40 \\
\hline AC & -0.114 & -0.009 & 0.173 & 0.207 & -0.03 & 0.165 & 0.030 & 0.128 & 1.000 & & & 1.47 \\
\hline BIG4 & -0.067 & -0.093 & 0.286 & 0.166 & -0.04 & 0.122 & -0.069 & 0.1655 & 0.170 & 1.000 & & 1.32 \\
\hline ML & 0.101 & 0.062 & 0.110 & 0.178 & -0.05 & -0.056 & -0.185 & -0.011 & -0.04 & 0.099 & 1.000 & 1.13 \\
\hline
\end{tabular}

\subsection{The multivariate analysis}

Concerning the disclosure index, we opted for the use of quartiles to split the sample between companies providing good information quality and companies with low disclosure quality. We obtain transparent and opaque firm. We used the second quartile $(\mathrm{Q} 2=50 \%)$, companies whose score is lower than the calculated second quartile that is 0.8076 are considered as companies offering poor quality information and opaque. Against those with a value for the index above 0.8076 are considered as transparent and disclose information with high quality.

The dependent variable in this case becomes:

Disclosure Quality $=0$ if the index is lower than 0.8076

$$
=1 \text { if not }
$$

The binary nature of variable and the study focuses on 101 companies over five years leads us to use the panel logit model. Whose distribution function is represented as follows:

$$
\log \left(\frac{p}{1-p}\right)=\beta_{0}+\sum_{i=1}^{n} \beta_{i} x_{i, t}
$$

To detect the relationship between the quality of financial information disclosed and its determinants specifically those relating to corporate governance, we use many variables related to governance. Four variables describing the characteristics of the board (board size, presence of independent director, the combination of functions and attendance at meetings), two variables on the ownership structure (percentage held by institutional investors and percentage held by 
the major shareholder) and finally two variables measuring the quality control (presence of the Audit Committee and audit firm size).

Since we have two measures for the quality of financial information that is the extent of disclosure index and the discretionary accruals (Shahrur and Raman, 2008) this step allows us to have the two equations below:

\section{Equation 1:}

DACC $_{i, t}=\beta_{0}+\beta_{1} \quad \mathrm{LEV}_{i, t^{+}} \beta_{2} \quad \mathrm{PRO}_{\mathrm{i}, \mathrm{t}^{+}} \beta_{3} \quad \mathrm{NB}_{\mathrm{i}, \mathrm{t}^{+}} \beta_{4} \quad \mathrm{IND}_{\mathrm{i}, \mathrm{t}^{+}} \beta_{5} \mathrm{MA}_{\mathrm{i}, \mathrm{t}}+\beta_{6} \quad \mathrm{DUA}_{\mathrm{i}, \mathrm{t}}+\beta_{7} \quad \mathrm{INST}_{\mathrm{ii}, \mathrm{t}}$ $+\beta_{8} O W N_{i, t}+\beta_{9} A C_{i, t}+\beta_{10} B I G 4 i, t+\beta_{11} M L_{i, t}+\beta_{12} M A N_{i, t}+\varepsilon_{i, t}$

\section{Equation 2 :}

$D Q_{i, t}=\beta_{0}+\beta_{1} \quad \mathrm{LEV}_{\mathrm{i}, \mathrm{t}^{+}} \beta_{2} \quad \mathrm{PRO}_{\mathrm{i}, \mathrm{t}^{+}} \beta_{3} \quad \mathrm{NB}_{\mathrm{i}, \mathrm{t}^{+}} \beta_{4} \quad \mathrm{IND}_{\mathrm{i}, \mathrm{t}^{+}} \beta_{5} \mathrm{MA}_{\mathrm{i}, \mathrm{t}}+\beta_{6} \mathrm{DUA}_{\mathrm{i}, \mathrm{t}}+\beta_{7}$ INST $_{\mathrm{ii}, \mathrm{t}}+$ $\beta_{8} O W N_{i, t}+\beta_{9} A C_{i, t}+\beta_{10} B I G 4, t+\beta_{11} M_{i, t}+\beta_{12} M A N_{i, t}+\varepsilon_{i}$,

$D Q$ : disclosure quality;

DACC: discretionary accruals;

Lev : leverage;

PRO: The Profitability (Qtobin);

NB: numbers of members in the board of directors;

IND: independent directors (members extern / total members in board);

MA: percentage of attendance of members at meetings;

DUA: duality of function for manager;

INST: The institutional investors;

OWN : the percentage owned by the majority shareholder ;

AC: Audit Committee;

BIG4: presence of an auditor belonging to BIG4;

ML: Multiple listing;

MAN: manufacturing industry.

For the model where quality information is approximated by discretionary accruals, we found that the quality of information is better for a company with a higher performance. There is a negative relationship between discretionary accruals and Tobin's Q. The same result is obtained by Becker et al, (1998). In fact, a profitable firm has growth opportunities, it may disclose more information to indicate the credibility of its reported earnings and the projects that it expects to achieve. This will increase its reputation and avoid under-evaluation of its actions. This relationship can also be explained also by the behavior of managers. These provide more information to illustrate their ability to maximize value for shareholders and at the same time increase their compensation.

Variable on the multiple listing has a positive coefficient and it is significant at the $1 \%$ level. Indeed in the presence of a foreign listing, the company seeks to follow the international standards where there are more requirements in term of disclosure and quality of information.

With dual listing the company may have an advertisement by the attraction of the press and the satisfaction of information needs of local users. It also allows to the company to access to more liquid financial markets than its domestic market. Our results are similar to those found by Cooke (1989), Wallace et al, (1994), Inchausti (1997), Leventis and Weetman (2004), Prencipe (2004) and Gray and Leung (2005).

Table 5. The estimation results of the determinants of the quality of financial disclosure

\begin{tabular}{|l|r|r|r|r|}
\hline & \multicolumn{2}{|c|}{ Equation 1 } & \multicolumn{2}{c|}{ Equation 2 } \\
\hline \multicolumn{1}{|c|}{ Variables } & coefficient & t-statistics & \multicolumn{1}{c|}{ coefficient } & \multicolumn{1}{c|}{-statistics } \\
\hline LEV & -.0105306 & -0.85 & -5.804071 & -1.14 \\
\hline PRO & $-.0125385^{\star * *}$ & -4.32 & -.2272125 & -1.14 \\
\hline NB & $-.0014263^{* \star *}$ & -2.92 & -.3518097 & -1.39 \\
\hline
\end{tabular}




\begin{tabular}{|l|r|r|r|r|}
\hline IND & -.0082159 & -0.86 & -0.9305052 & -0.29 \\
\hline MA & $-.046118^{* *}$ & -2.23 & $19.35026^{* * *}$ & 2.89 \\
\hline DUA & -.0051072 & -1.33 & $-7.974536^{* * *}$ & -4.37 \\
\hline INST & $0.0078676^{* *}$ & 2.03 & -1.142322 & -0.71 \\
\hline OWN & .0115638 & 1.26 & -5.535982 & -1.31 \\
\hline AC & -.0020915 & -0.51 & 3.172463 & 1.24 \\
\hline BIG4 & $-.0071458^{* *}$ & -2.40 & 1.703402 & 1.36 \\
\hline ML & $-0.123979^{* * *}$ & -3.49 & $10.43558^{* * *}$ & 5.43 \\
\hline MAN & $.0123979^{* * *}$ & 3.07 & $3.136482^{*}$ & 1.80 \\
\hline Constante & $.0569653^{* * *}$ & 2.60 & $-14.8693^{* * *}$ & -2.06 \\
\hline Wald chi2(13) & $74.11^{* * *}$ & & $58.19^{* * *}$ & \\
\hline
\end{tabular}

$\left.\left({ }^{*}\right),{ }^{* *}\right)$ and $\left.{ }^{* * *}\right)$ respectively significant at a level of $10 \%, 5 \%$ and $1 \%$.

For governance variables, we found that the quality of financial information is important for a company follows by an auditors belonging to the big 4. Unlike Janin and Piot (2008) did not detect relationship between the size of audit firm and earning management. The existence of large audit firm improves the efficiency of the control system and can encourage managers to disclosure more information and give a more credibility. According to the literature the independence, expertise, reputation and the size of audit firm can be considered as barriers to the earning management and the information published may be better(Xie et al, 2003, Cormier and Martinez, 2006, and Carcello et al, 2006).

The attendance of Board members at meetings has a negative effect on earning management. This relationship is represented by a negative and significant coefficient at the $5 \%$ threshold and therefore there is an impact positive on the quality of information disclosed by the French listed companies. Indeed, members can attend to exercise some control and helps in decision making at meetings and production of data.

The size of the board has an impact on the quality of the information measured by discretionary accruals. This is shown by the presence of a significant relationship at the $1 \%$ level. This result demonstrates that the earning management increases when the board is composed by small number of directors. This result is contrary to that found by Kao and Chen (2004), Bita and Majella (2008) and similar to those of Xie et al, (2003) and Bradbury et al, (2004). Firth et al (2007) for a sample of Chinese firms, based on data from 1998 to 2003, not found a significant relationship between the size of the board and the quality of financial information approximated by discretionary accruals .

Large Board are more effective than small board since it contains more experienced directors, and play an important role in limiting earnings management (Xie et al, 2003). There is a positive relationship between the size of the board of directors and the quality of accounting information and therefore a lower level of discretionary accruals (Bradbury et al, 2004).

As for the variable on the presence of institutional investors, we found a positive relationship and significant at the $1 \%$ level with discretionary accruals. This variable has an unexpected sign. This result is similar to study of Cornett et al. (2007). Institutional shareholder can increase the pressure felt by the manager to meet earnings forecasts causing it to engage in earnings management. The effectiveness of the presence of institutional investors depends on the size of their shareholdings in the firm. These investors will have no incentive to monitor managers when their share of capital is low (Lang and McNichols, 1999). On the other hand, Chau and Gray (2002) argue that when the ownership structure is concentrated, large institutional investors are not concerned about the voluntary disclosure, since they have access to information in the firm.

Regarding industry, we found that firms in manufacturing industry do not provide enough quality information.

We found among the variables not significant, leverage, combining the functions of CEO and chairman of the board of directors and ownership concentration, the presence of the Audit Committee and the existence of independent directors. This result is similar to those of Bédard et al., (2001); Park and Shin (2004).

Concerning the inclusion of the second quartile as a measure of the quality of financial information disclosed, we found the attendance of members at meetings of the Board, the duality of functions and the presence of dual listing are significant at a level of $1 \%$. All signs are expected. The variable concerning duality of function acts negatively on the quality of financial information disclosed. According to the agency theory the separation of management and control decisions reduces agency costs and increase company performance. Our results are similar to those of Beasley (1996), 
Ho and Wong (2001), Chtourou, Bedard and Courteau (2001), Gul and Leung (2004). The separation of function increases the effectiveness of the Board and improves the quality and level of information disclosed by companies. The result for the activity sector shows that firms in the manufacturing industry communicate more financial information. This result is significant at the $10 \%$ level. This result is contrary to that found for the first measure of the quality of the information disclosed.

\section{Conclusion}

In this study we tried to find factors that can influence the quality of financial information approximated by two variables, the disclosure index and discretionary accruals. The factors are firm-specific characteristics and those related to corporate governance. Our results show that the size of the Board, attendance of members at meetings of the Board, the presence of the auditors belonging to the big 4 and the presence of a double listing have a positive impact on the quality of information financial disclosed. By against, the presence of institutional investors gives contrary results. This last result is defended by Paquerot (1997) and Lang and McNichols (1999), Chau and Gray (2002).

One potential limitation of studies is the use of disclosure index as a measure of the quality of disclosure. The issue of subjectivity of disclosure index has a significant impact on the development of generalized measures of disclosure level. Many problems may exist due to the self-construction of index (Healy and Palepu, 2001).

In our study, the annual report is used as a support for the construction of the disclosure index. The Company has other means of communication of information which may be taken into account such as the media or the internet. Using annual report may limit somewhat the scope of disclosure of corporate financial information.

Further research may take a number of directions. Disclosure policies of listed companies have generally changed after the adaptation of international accounting standards (IAS / IFRS) on 2005. Henceforth, it is useful to extend this study by taking into account the effect of international standards adopted on the disclosure level by French companies.

Similarly, the introduction of new laws as Saranes-Oxley Act may encourage companies to disclose more information. The study of the impact of these laws is also interesting. The study of the importance of intangible information and that relating to social responsibility for companies can be the subject of future research. Similarly, the publication of information through web sites is an important support for business. As future research can focus on the information and the integration of various communication media and not be limited only to annual reports. Use also the technique of event studies may even indicate the effect of the information disclosed.

\section{References}

Agca A. \& Önder S. (2007).Voluntary Disclosure in Turkey: A Study on Firms Listed in Istanbul Stock Exchange (ISE). Problems and Perspectives in Management.5(3).241-251.

Ahmed, K., \& Courtis, J. K. (1999). Association between corporate characteristics and disclosure levels in annual reports: A meta-analysis. British Accounting Review. 31, 61-65.

Akhtaruddin(2005), "Corporate mandatory disclosure practices in Bangladesh. The International Journal of Accounting.40.399422

Aksu, M. \& Kösedağ, A. (2006). Transparency and disclosure scores and their determinants in the Istanbul Stock Exchange. Corporate Governance: an International Review.14(4) .277-296.

Arcay R B \&Vázquez F M, (2005). Corporate characteristics, governance rules and the extent of voluntary disclosure in Spain. Advances in Accounting. 21.299-331.

Archambault, J. \& Archambault, M. (2003).A multinational test of determinants of corporate disclosure. The International Journal of Accounting. 38. 173-194.

Barako D.G. HancockP. ., \& Izan H.Y.(2006).Factors Influencing Voluntary Corporate Disclosure by Kenyan Companies. Corporate Governance: An International Review. 14(2) . 107-125,

Beasley, M.S., (1996). An Empirical Analysis of the Relation between the Board of Director Composition and Financial Statement Fraud. The Accounting Review. 71. 443-465.

Bédard, J., Chtourou,M.,\& Courteau, L. (2001). Corporate governance and earning management, Document de recherche, Université Laval.

Ben Ayed-Koubaa H.(2010).L'impact des mécanismes internes de gouvernement de l'entreprise sur la qualité de l'information comptable. Cahier de recherche Prism-sorbonne, №18.

Bita, M. \& Majella, P. (2008). The role of the audit committe and institutional investors in constraining earnings management: evidence from chinese firms listed in Hong Kong, Working Paper. 
Botosan, C. A., \& Plumlee, M. A. (2002).A re-examination of disclosure level and the expected cost of equity capital. Journal of Accounting Research. 40(1). 21-40

Bradbury, M. E. (1992). Voluntary disclosure of financial segment data: New Zealand evidence. Accounting and Finance 32 (1).15-26.

Bradbury, M.E., Mark, Y.T \& Tan, S.M. (2004).Board characteristics, audit committee characteristics and abnormal accruals Accounting Law and Finance. 1- 27.

Brickley J. A., Coles J. L. \& Jarrell G. (1997). Leadership structure: Separating the CEO and Chairman of the Board, Journal of Corporate Finance. 3.189-220.

Bujaki, M. \& McConomy, B. (2002).Corporate governance: factors influencing voluntary disclosure by publicly traded Canadian firms, Canadian Accounting Perspectives, Vol. 1, No. 2, pp. 105-139.

Bushee, B.J. \& C.F. Noe.( 2000). Corporate Disclosure Practices, Institutional Investors, and Stock Return Volatility. Journal of Accounting Research. 38 (supplement).171-202.

Bushman, R.M., J.D. Piotroski, \& A.J. Smith, (2004). What Determines Corporate Transparency?, Journal of Accounting Research. 42. 207-252.

Campos C.E., Newell.R.E., \& Wilson G.(2002). Corporate governance develops in emerging markets. McKinsey On Finance.15-18.

Carcello, J.V., Hollingsworth, C.W. \& Klein, A. (2006).Audit Committee Financial Expertise, Competing Corporate Governance Mechanisms, and Earning Management. Working Paper, University of Tennessee.

Cerf, A. R. (1961) . Corporate Reporting and Investment Decisions, Berkely, California: The University of California Press.

Chau G. K., \& Gray S. J. (2002). Ownership structure and corporate voluntary disclosure in Hong-Kong and Singapore, The International Journal of Accounting. 37( 2). 247-265.

Chavent M., Ding Y., Fu L., Stolowy H.,\& Wang H., (2006). Disclosure and Determinants Studies: An Extension Using the Divisive Clustering Method (DIV). European Accounting Review. 15( 2). 181 - 218.

Chen, J.P., Charles, \& Jaggi, B. L. (2000) . The Association between independent nonexecutive directors, family control and financial disclosures in Hong Kong . Journal of Accounting and Public Policy. 19(4-5).285-310.

Cheung, Y.-L., Jiang P., \& Tan W.(2010). A transparency Disclosure Index measuring disclosures:Chinese listed companies. Journal Account. Public Policy.

Chung, R., Firth, M. \& Kim, J. (2002). Institutional monitoring and opportunistic earnings management. Journal of Corporate Finance. 8.29-48.

Chow CW, \& Wong-Boren A (1987). Voluntary financial disclosure by Mexican corporations. The Accounting Review. 62(3): 533541.

Christiaens, J. (1991). Financial Accounting Reform in Flemish Municipalities: An Empirical Investigation. Financial Accountability and Management. 15(1). 21-40.

Chtourou, M. S, Bédard, J \& Courteau, L (2001). Corporate governance and earnings management, Working paper, Laval University. 1-41.

Clarkson P. M., Ferguson C., \& Hall J. (2003). Auditor conservatism and voluntary disclosure : evidence from the year 2000 systems issue, Accounting and Finance. 43. 21-40.

Cooke, T. E. (1992). The Impact of Size, Stock Market Listing and Industry Type on Disclosure in the Annual Reports of Japanese Listed Corporations. Accounting and Business Research. 22 (87).229-237.

Cormier, D. \& Martinez, I. (2006). Voluntary Disclosure of Management Earnings Forecasts in French IPO's: The Impact on the Quality and Relevance of reported Earnings. International Journal of Accounting. 41(2). 209 - 236.

Cornett, M.M., Marcus, A.J., Saunders, A. \& Tehramian, H., (2007).The impact of institutional ownership on corporate operating performance. Journal of banking and finance. 31. 1771-1794.

Cormier D. \& Gordon I. M. (2001).An Examination of Social and Environmental Reporting Strategies. Accounting, Auditing and Accountability Journal. 14 (5). 587-616.

Dahya, J., Lonie, A.A. \& Power, D.M. (1996). The Case For Separating the Roles of Chairman and CEO: An Analysis of Stock Market and Accounting Data, Corporate Governance-An International Review, April.4.71-77

Datar , S. \& Feltham, G. and Hughes, J. (1991). The role of audits and audit quality in valuing new issues, Journal of Accounting and Economics. 14(1). 3-49.

DeAngelo, L.E. 1981. Auditor Size and Audit Quality. Journal of Accounting and Economics. 3:183-199.

Denis D.J., Denis D., \& Sarin A., (1997), Agency problems, equity ownership, and corporate diversification, Journal of Finance. 52(1). 135-160.

Depoers, F. (2000). A cost-benefit study of voluntary disclosure: Some empirical evidence from French listed companies. The European Accounting Review.9(2), 245-263.

Dye, R. \& S. Sridhar. Industry-wide Disclosure Dynamics. Journal of Accounting Research.(3). 157-74.

Eng, L. L. \& Mak, Y. T. (2003) "Corporate governance and voluntary disclosure, Journal of Accounting and Public Policy. 22. 325-345. 
Fama E., (1980). Agency problems and the theory of the firm. Journal of Political Economy. 88. 2. 288-307.

Fama, E.,\&Jensen, M. (1983). Separation of ownership and control, Journal of Law and Economics. 26.301-325.

Fan J. P. \& Wong T.J. (2005). Do External Auditors Perform a Corporate Governance Role in Emerging Markets? Evidence from East Asia , Journal of Accounting Research. 43 (1).

Fernández C., \& Arrondo R., (2005). Alternative internal controls as substitutes of the board of directors , Corporate Governance. Oxford. 13(6.) 856-878.

Firth M., Fung P. \& Rui O., (2007). Ownership, two-tier board structure, and the informativeness of earnings -Evidence from China. Journal of Accounting and Public Policy. 26. 463-496.

Francis, J. R., Khurana I.K., \& Pereira R., (2005). Disclosure Incentives and Effects on Cost of Capital Around the World, Accounting Review. 80. 1125-1162.

Franks, J. \& Mayer, C. (2001). Ownership and control of German corporations. Review of Financial Studies. 14(4). 943-77.

Godard L., (2001).La taille du conseil d'administration : déterminants et impact sur la performance. Cahier du FARGO $n^{\circ}$ 1010702.

Godard L., \& Schatt A., (2000). Faut-il limiter le cumul des fonctions dans les conseils d'administration ? , La Revue du Financier. 127. 36-47.

Gainet C., Saidane D., Farvaque E., \& Refait Alexandre C., (2009). Is Corporate disclosure Necessarily Desirable? A Survey, http://papers.ssrn.com/abstract_id=1416622.

Gul F., \& Leung S.(2004). Board leadership, outside directors' expertise and voluntary corporate disclosures, Journal of Accounting and Public Policy. 23. 351-379.

Hambrick DC, \&Abrahamson E: (1995). Assessing Managerial discretion across Industries: A Multi-method Approach. Academy of Management Journal. 38.1427-1441.

Hanifa, R. M. \& Cooke, T. E. (2002). Culture, corporate governance and disclosure in Malaysian corporations, ABACUS. 38 (3). 317-349.

Hanifa, M.H., \& Ab. Rashid, H. (2005). The determinants of voluntary disclosures in Malaysia: The case of internet financial information disclosed. UNITAR E-Journal 2(1). 22-42.

Hartzell, Jay \& Starks, L. (2003). Institutional investors and executive compensation. Journal of Finance. 52. 2351-2374.

Hassan Omaima A.G., Romilly Peter, \& Gianluigi Giorgioni(2006). The extent of financial disclosure and its determinants in an emerging capital market: the case of Egypt, International Journal of Accounting, Auditing and Performance Evaluation. 3(1).41-67.

Healy, P. M. \& Palepu, K. G. (2001). Information asymmetry, corporate disclosure, and the capital markets: A review of the empirical disclosure literature, Journal of Accounting and Economics. 31. 405-440.

Healy, P. M. \& J. M. Wahlen. (1999). A review of the earnings management literature and its implications for standard setting. Accounting Horizons.12. 365-383

Ho L. \& Taylor M.E. (2007), "An Empirical Analysis of Triple Bottom-Line Reporting and its Determinants: Evidence from the United States and Japan, Journal of International Financial Management \& Accounting, Volume 18, Issue 2, pages 123 150 ,

Ho, S. S. M., \& Wong, K. S. (2001). A study of the relationship between corporate governance structures and the extent of voluntary disclosure. Journal of International Accounting, Auditing and Taxation. 10. 139-156.

Inchausti, B.G. (1997). The Influence of Company Characteristics and Accounting regulation on Information Disclosed by Spanish Firms. The European Accounting Review.6(1).45-68.

Jaggi, B. \& Low, P. Y. (2000). Impact of culture, market forces, and legal system on financial disclosures. The International Journal of Accounting. 35(4). 495-519.

Jensen, M. C., \& Meckling, W. H. (1976). Theory of the firm: Managerial behavior, agency costs and ownership structure. Journal of Financial Economics.3(3).305-360.

Jensen, M.C.(1993). The Modern Industrial Revolution, Exit, and the Failure of the Internal Control Systems, Journal of Finance. 48. 831-880.

Janin R. \& Piot C. (2008). L'influence des auditeurs externes et des comités d'audit sur le contenu informatif des manipulations comptables. La Revue des Sciences de Gestion . 5(3).23-33.

Jiang W., Lee P. \& Anandarajan, A. (2008).The association between Corporate Governance and Earning Quality: Further evidence using the Gov-Score. Advances in Accounting, incorporating Advances in International Accounting.24(2).191201

Kao L. \& Chen A. (2004).The effects of board characteristics on earnings management, Corporate ownership and control.1(3). 99-107

Khanna, Palepu \&Srinivasan (2004).Disclosure Practices of Foreign Companies Interacting with U.S. Markets, Journal of Accounting Research.42(2). 475-508.

Kothari, S.P., Leone A.J \& Wasley C.E. (2005). Performance matched discretionary accrual measures. Journal of Accounting and Economics.(39).163-197. 
La Porta R., Lopez-de-Silanes F., Shleifer A. \&Vishny R. (2000). Investor protection and corporate governance. Journal of Financial Economics. 58(10). 3-27.

Lang, M. \& Lundholm, R. (1993).Cross-sectional determinants of analyst ratings of corporate disclosures, Journal of Accounting Research. 31(2). 246-271.

Lang, M., \& Mc Nichols M., (1999).Institutional Trading, Corporate Earnings and Returns. Working paper. Stanford University.

Leung Q W Y, Morris R D \& Gray S J, (2005). Corporate transparency in China: Factors influencing financial disclosure levels.working paper, School of Accounting, University of New South Wales.

Leventis S. \& Weetman P. (2004). Timeliness of financial information disclosed: applicability of disclosure theories in emerging capital market, Accounting and Business Research.34 (1). 43-56.

Li H., Qi A.,(2008).impact of corporate governance on voluntary disclosure in Chinese listed companies. Corporate Ownership \& Control .5(2).360-366.

Lu C, Lia G.M, \& Yang Y. (2007).Ownership Structure, Information Disclosure and Corporate Value: An Empirical Analysis of Taiwan Companies, Proceedings of the 13th Asia Pacific Management Conference, Melbourne, Australia.698-704.

Mc Kinnon, J.L., \& Dalimunthe, L. (1993).Voluntary disclosure of segment information by Australian diverisified companies, Accounting and Finance.33. 33-50.

McMullen, D., (1996). Audit Committee Performance: An Investigation of the Consequences Associated with Audit Committees. Auditing: A journal of Practice and Theory.15. 87-103.

Molz R., (1988).Managerial Domination of Boards of Directors and Financial Performance. Journal of Business Research.16. 235-250.

Morris, R.D. B.U.S. Ho, T. Pham \& S.J. Gray, (2004). Financial information disclosed Practices of Indonesian Companies Before and After the Asian Financial Crisis Asia-Pacific Journal of Accounting \& Economics. 11 (2). 1-27.

Paquerot M. (1997). Stratégies d'enracinement des dirigeants, performance de la firme et structures de contrôles. In G. CHARREAUX, ed, Le gouvernement des entreprises : Corporate governance théorie et faits. Paris : Economica. 105138.

Park, Y.W. \& Shin, H.H. (2004).Board Composition and earnings Management in Canada , Journal of corporate Finance. 10. 431- 457.

Pearce J., \& Zahra S., (1992). Board composition from a strategic contingency perspective ,Journal of Management Studies. 29. 411-438.

Prencipe, A. (2004).Proprietary costs and determinants of voluntary segment disclosure: evidence from Italian listed companies.European Accounting Review. 13(2). 319 -340.

Raffournier, B. (1995). The determinants of voluntary financial disclosure by Swiss listed companies. The European Accounting Review. 4(2).261-280.

Raman, K. \& H. Shahrur,(2008). Relationship-specific investments and earnings management: Evidence on corporate suppliers and customers. Accounting Review. 83.1041-1081.

Vafeas, N. (1999).Board Meeting frequency and firm Performance. Journal of Financial Economics. 53. 113-142.

Van Der Laan Smith, J., Adhikari, A., \& Tondkar, R. H. (2005). Exploring differences in social disclosures internally: A stakeholder perspective. Journal of Accounting and Public Policy. 24. 123-151.

Verrechia, R. (1983) .Discretionary disclosure, Journal of Accounting and Economics. 5.179-194.

Wang K., Sewon O., \& Claiborne M.C.,(2008).Determinants and consequences of voluntary disclosure in an emerging market: Evidence from China. Journal of International Accounting, Auditing and Taxation .17 . 14-30.

Watson, A., Shrives, P. \& Marston, C. (2002).Voluntary disclosure of accounting ratios in the UK, British Accounting Review. 34. 289-313.

Xiao, J. Z., Yang, H. \&Chow, C. W. (2004). The determinants and characteristics of voluntary Internet-based disclosures by listed Chinese companies. Journal of Accounting and Public Policy.. 23. 191-225.

Xie, B., W. Davidson, \& P. DaDalt. (2003). Earnings management and corporate governance: the role of the board and audit committee. Journal of Corporate Finance. 9: 295-316.

Yermack D., (1996). Higher market valuation of companies with a small board of directors,.Journal of Financial Economics. 40(2). 185-211.

Zeghal D., Chetourou S.M., \& Fourati Y.M.(2006), Impact de la structure de propriété et de l'endettement sur les caractéristiques du conseil d'administration , 27 ième Congrés AFC. 
Appendix : List of item for disclosure index

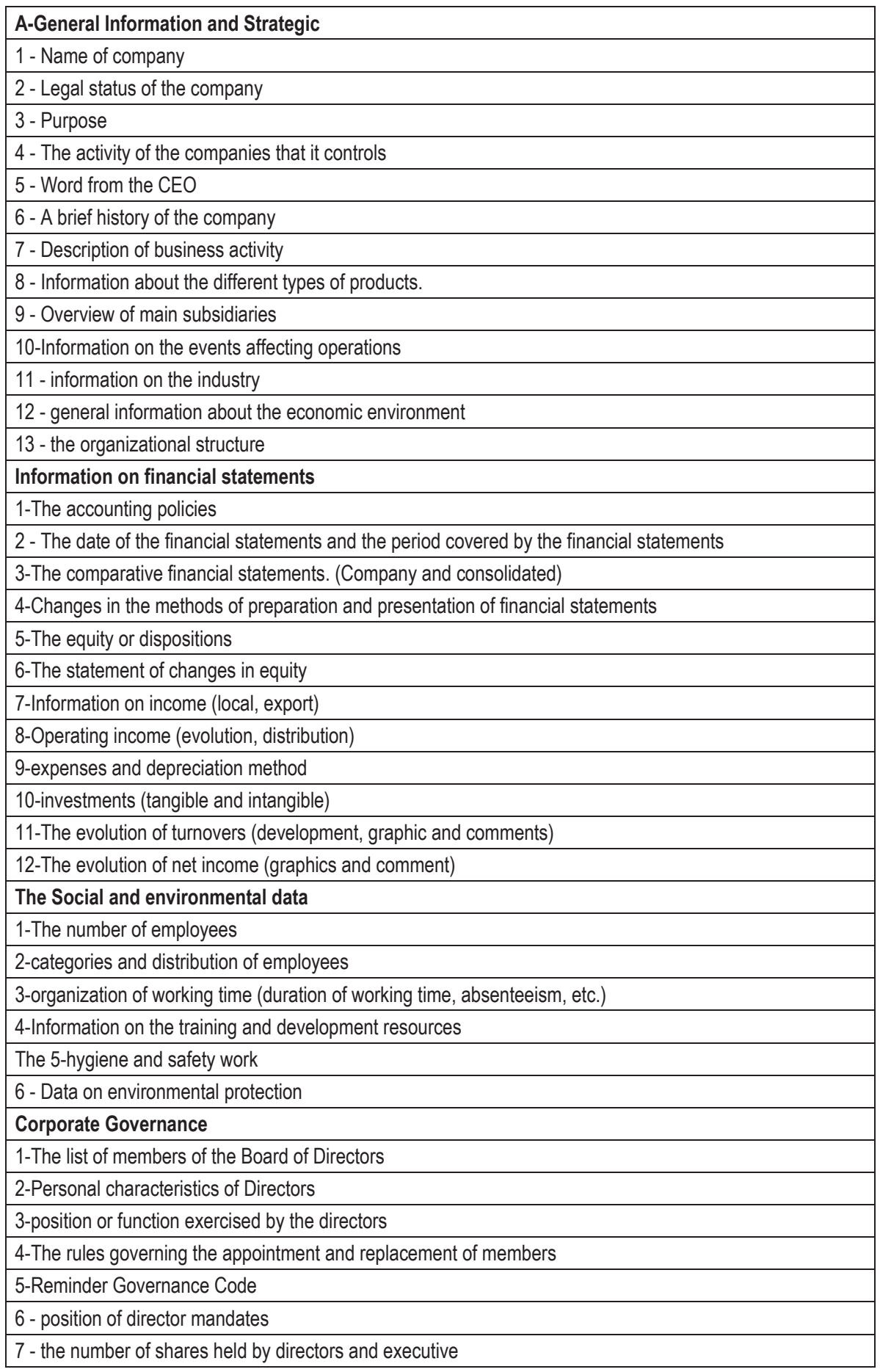


8-The shareholders

9-The composition of the shareholding.

10-The auditor (situations mandates, fees, etc. ..)

11-employee participation in capital

12- The presence of committees (audit, remuneration, nomination etc. ..)

13-List of directors

14- the members of the Executive

15-operation of the Executive

16 - Compensation of Directors and Executive Board

17-the stock option plan (directors, employees, directors)

18-conflicts of interest between the Board and the Executive

Financial and market information

1-The number of shares and the par value per share

2 - The market value of shares

3-The market value of equity investments

4-Information on the share capital and voting rights

5-The evolution of stock prices and transactions (trading volume)

6-The market capitalization at year-end, trend

7-The dividend policy of the company

8-The dividends paid for the last three years (evolution)

9TheDividends per share.

10-Earnings per share

11-The evolution of capital (nature of the transaction, the outstanding capital)

12-The information on new issues

13-The evolution of the financial structure (Working Capital Fund)

14-The liquidity ratio

15-The debt ratio

16-The solvency ratio

17-The price / earnings ratio (PER)

18-profitability ratios (ROA, $\mathrm{ROE}$ )

Looking information

1-Information on future

2-Discuss the main factors influencing the next fiscal year

3-The earnings estimates for 3 years

4-Projections of future cash flows for 3 years

Other information

1-The report of the Board of Directors.

2-The report of the auditor

3-The resolutions $\mathrm{dd} / \mathrm{mm} /$ yyyy

4-The activity indicators

5-The elements of internal control,

6- Risk management policy

7-activities in research and development 